cetologist, especially on the often difficult decisions of identification: people from all parts of the world came for his help. His numerous taxonomical notes, mostly on rarer species, provided clarification where there was usually utter confusion.

In 1956 he described a species of dolphin Lagenodelphis hosei from a single skeleton collected before 1895 on a beach in Sarawak. From 1971 onwards sightings and captures have been made in widely scattered parts of the world to 're-discover' what is now known as Fraser's dolphin.

He contributed original observations on the anatomy, especially cranial osteology, and morphology of many cetacean species and made use of stranded animals brought to the museum both for research and display. The Whale Hall's present existence and its popularity owe much to Fraser's desire to educate the public about whales and dolphins. He also supported many of the early enterprises to exhibit live dolphins. His informative museum guides to British cetaceans and his splendid book with J. R. Norman, Giant Fishes, Whales and Dolphins are meticulously accurate.

A substantial work was that with P. E. Purves on Hearing in Cetaceans (Bull. Brit. Mus. (Nat. Hist.) Zool. $1960,7,1)$. This dealt with anatomical and experimental evidence to demonstrate that hearing was by way of the external auditory meatus, it was precisely discriminative and directional and the cetacean ear was sensitive to a wide range of frequencies. The elaborate sinus system was shown to be an extension of the middle ear cavity and could be a guide to the systematic arrangement of the Order Cetacea.

Fraser had a deep interest in the history of cetology and wrote about Peter Mundy's Greenwich Whale of 1568, early Japanese whaling, William Scoresby Junior and on the Grey Whale in Icelandic waters. His last contribution (1977) was on 'Royal Fishes: The Importance of the Dolphin'. This paper contained a lifetime's research and reflection on the Royal Prerogative in Britain which he had traced back as far as the 13th century.

Fraser was proud of his Dingwall stock and delighted in being a pawky Scot of the dry, humorous kind: yet there was nothing but solicitude and generosity about him, consideration for anyone deserving of it and an unrelenting determination to see justice done. It could well have been of him that Herman Melville wrote: 'But I have swam through libraries and sailed through oceans; I have had to do with whales with these visible hands; I am in earnest; and I will try.'

R. J. Harrison

\section{A. S. McFarlane}

Arthur Sproul McFarlane, Head of the Biophysics Division at the National Institute for Medical Research from 1945 to 1970 died on 4 October 1978.

$\mathrm{He}$ was born in Glasgow on 18 April 1905. He took 1st class honours in biochemistry at Glasgow University in 1928, and qualified in medicine in 1931. From 1931-33 he was biochemist at the Glasgow Royal Cancer Hospital, and was elected to a Beit Memorial Fellowship in 1933 to work in Uppsala under Professor The Svedberg on the use of the recently developed oil-turbine ultracentrifuge. The studies which he made of a wide range of serum proteins illustrated the potential of this new technique for the characterisation of normal and pathological proteins in mixtures.

When the Rockefeller Foundation, anxious to make the instrument available to other laboratories, offered one to the Lister Institute, McFarlane joined the Institute to continue his Beit Fellowship and to supervise the installation of the Svedberg machine in a specially constructed building. The installation was completed in 1937 , by which time he had become a member of the Lister Institute staff and had been joined by R. A. Kekwick. They also acquired the newly developed Tiselius electrophoresis apparatus-both instruments being the first of their kind in the UK-and in 1938 published the first paper arising from their use on the "Physical properties of bushy stunt virus" recently crystallised by F. C. Bawden and N. W. Pirie.

Further work on vaccinia virus was interrupted by the war, when his attention changed to devising a means for preparing stable human plasma for transfusion. He invented a novel means of removing unstable lipids by freezing below $-25^{\circ} \mathrm{C}$ with ether, and went on to design large scale freeze drying plant. This was done at the L.C.C. Serum Institute, Carshalton, where the laboratory had been transferred in 1941.

In 1943 McFarlane's services were requested by the National Institute for Medical Research to supervise the design and installation of special services, including one of the early electron microscopes, in the new building at Mill Hill (built in 1938 but used meanwhile by units of the Women's Royal Naval Service and finally occupied in 1950).

When in 1945 the US Atomic Energy Commission announced that radioisotopes produced in uranium chainreactors would be available for peaceful uses to scientists all over the world, McFarlane was sent by the Medical Research Council to negotiate the supply of radioisotopes for the UK.
Hopes were rudely shattered by the passage in 1946 of the McMahon Act forbidding exportation from the US of all radioactive materials produced in atomic piles, but McFarlane through his friendship with Robley Evans, in charge of the cyclotron at the Massachussetts Institute of Technology, managed to obtain sufficient ${ }^{32} \mathrm{P}$ to allow research workers here to get the feel of radioisotopes and experience in design of counting instruments.

In 1947 he was again sent to the US and to Canada to negotiate purchase of other radioisotopes and this mission was entirely successful. (A fuller account appears in an article by Professor George Popjak in Trends in Biochemical Sciences, October 1976.)

By the time that the N.I.M.R. finally moved to Mill Hill in 1950 McFarlane had been responsible for making it the best equipped medical research laboratory in England in respect of biophysical instrumentation. By designing an elaborate but efficient apparatus for counting ${ }^{14} \mathrm{C}$ after combustion to ${ }^{14} \mathrm{CO}_{2}$ and installing a mass spectrometer he also gave his colleagues a headstart in the use of the radioactive and stable isotopes then available.

His own interests became concentrated on studying the metabolism of plasma proteins, using ${ }^{14} \mathrm{C}$ and radioiodine as trace labels. He devised a method for labelling proteins with radioiodine, which avoided denaturation and by studies on antibodies in collaboration with J. H. Humphrey showed that biological activity and ${ }^{14} \mathrm{C}$ internal and ${ }^{131} \mathrm{I}$ external labels were catabolised at identical rates. This validated radioiodine labelling and led to a series of definitive measurements on the turnover of several plasma proteins in normal and sick subjects, in which McFarlane collaborated with workers in Britain, the USA and elsewhere. He also developed an ingenious method for measuring plasma protein synthesis in vivo involving simultaneous measurement of incorporation of ${ }^{13} \mathrm{C}$ from labelled urea and ${ }^{14} \mathrm{C}$ from bicarbonate.

By temperament he was a shrewd Scotsman, with what might nowadays be considered an old fashioned outlook on life, but certainly capable of enjoying it. He was at his best when devising apparatus or techniques, and would have made his mark in industry had he chosen this career. Although his own approach to biological problems was simple (sometimes over-simple) and mathematical, he greatly helped many biological colleagues by providing them with technological back-up at a time when the array of sophisticated equipment nowadays provided by scientific instrument manufacturers was not available.

J. H. Humphrey 